\title{
Implementasi QR-Code pada Aplikasi E-Market Mandiri untuk Pemberdayaan Ekonomi Kreatif Berbasis Android
}

\author{
Desi Ramayanti ${ }^{1}$, Wawan Gunawan ${ }^{2}$, Imam Ibnu Faishal ${ }^{3}$ \\ 1,2,3Teknik Informatika, Fakultas IImu Komputer, Universitas Mercu Buana \\ JI. Meruya Selatan No 1, Kembangan, Jakarta Barat, Indonesia \\ e-mail: ${ }^{1}$ desi.ramayanti@mercubuana.ac.id, ${ }^{2}$ wawan.gunawan@mercubuana.ac.id, \\ 341516120049@student.mercubuana.ac.id
}

\begin{tabular}{llll}
\hline Informasi Artikel Diterima: 29-10-2020 & Direvisi: 03-12-2020 & Disetujui: 07-12-2020 \\
\hline
\end{tabular}

\begin{abstract}
Abstrak
Aplikasi E-Market mandiri merupakan sebuah aplikasi yang dirancang untuk memberikan kemudahan bagi masyarakat ketika akan melakukan transaksi pembelian pada toko yang terdapat pada lokasi sekitar. Pemberdayaan ekonomi masyarakat diharapkan dapat terwujud dengan adanya inovasi implementasi aplikasi tersebut. Aplikasi E-Market dirancang dengan konsep user friendly sehingga akan memberikan kemudahan kepada pengguna ketika akan menggunakan aplikasi. Karena konsep tersebut maka aplikasi dibuat dengan berbasis mobile smartphone yang pada umumnya setiap saat digunakan oleh masyarakat dengan menggunakan teknologi $Q R$-Code. Aplikasi dibuat dengan menggunakan konsep client-server sehingga setiap data yang terkirim akan disimpan pada database untuk keperluan pencatatan atau riwayat pada setiap transaksi pembelian. Sebanyak $90 \%$ mengalami peningkatan penjualan yang signifikan dan sebanyak $90 \%$ berhasil mempromosikan produk yang dijualnya dan juga sebanyak $94,4 \%$ responden memberikan penilaian yang sangat baik untuk hasil penjualan menggunakan aplikasi e-market mandiri.
\end{abstract}

Kata Kunci: e-market, user friendly, android

\begin{abstract}
The standalone E-Market application is an application designed to provide convenience for the public when making purchases at stores in nearby locations. It is hoped that the community's economic empowerment can be realized with the innovation in implementing the application. The E-Market application is designed with a user friendly concept so that it will provide convenience to users when using the application. Because of this concept, the application is made based on a mobile smartphone which is generally used by the public at any time by using QR-Code technology. The application is made using the client-server concept so that any data sent will be stored in the database for recording or history purposes for each purchase transaction. As many as $90 \%$ experienced a significant increase in sales and as many as $90 \%$ succeeded in promoting the products they sell and also as many as $94.4 \%$ of respondents gave very good ratings for sales results using the e-market mandiri application.
\end{abstract}

Keywords: e-market, user friendly, android

\section{Pendahuluan}

Perkembangan teknologi informasi saat ini memberikan perubahan yang signifikan terhadap kehidupan masyarakat sehari-hari. Terlihat pada perilaku masyarakat yang sangat akrab dengan perangkat teknologi baik masyarakat menengah ke atas maupun masyarakat menengah ke bawah, hampir semuanya mempunyai gadget dan menggunakannya dalam kegiatan sehari-hari. Berdasarkan laporan Menristekbrin (Ristekbrin, 2017) disebutkan bahwa jumlah pengguna smartphone di Indonesia pada tahun 2017 sudah mencapai $25 \%$ dari jumlah penduduk Indonesia atau sekitar 65 juta orang. Angka tersebut dinilai cukup potensial dan akan terus berkembang seiring dengan terjangkaunya harga smartphone pada saat ini, sehingga terbukanya peluang terhadap pemanfaatan media smartphone baik dalam bidang sosial, budaya dan tak terkecuali bidang ekonomi. Pada segi ekonomi, Indonesia merupakan salah satu negara potensial yang memiliki tingkat 
perkembangan daya saing pertumbuhan tertinggi di Asia Tenggara.

Jika melihat hasil survei Menristekbrin tersebut, bukan tidak mungkin jika sistem perekonomian akan beralih dari yang dilakukan secara manual menuju era digital (Gunawan, 2019). Terlebih lagi berdasarkan hasil survei Badan Pusat Statistik (BPS) yang tercantum pada halaman webnya menyatakan dari $84,84 \%$ usaha e-commerce berpenghasilan kurang dari 300 juta pada tahun 2018, 300 juta - 2,5 miliar sebanyak $11,72 \%$ dan sebanyak 3,44 dengan penghasilan $>2,5$ miliar (Statistik E-Commerce 2019, 2019).

Melihat dengan adanya kedua peluang tersebut sehingga perlu adanya inovasi yang dapat mendukung pemberdayaan ekonomi masyarakat (Putra \& Dwiasnati, 2020), mengingat terus berkembangnya sektor ekonomi pada bidang industri market online yang terus bergerak secara signifikan, sehingga saat ini telah nampak warung-warung tradisional yang bermunculan dengan menawarkan produknya menggunakan media online (Yuniar, 2020). Banyak sekali warga masyarakat saat ini beralih untuk pemenuhan kebutuhan sehari-hari dengan berbelanja secara online jika dibandingkan dengan berbelanja secara langsung ke warung-warung tradisional (Made et al., 2020)(Darussalam, 2018). Sehingga perlu upaya dari pemerintah agar sektor tersebut tidak dikuasai oleh kepentingan pihak asing yang dapat kapan saja melakukan ekspansi pada sektor ekonomi market online tersebut mengingat belum ada regulasi yang mengatur hal tersebut.

Pemanfaatan QR-Code pada aplikasi eshopping yang telah dirancang dan diimplementasikan berupa melakukan pemesanan barang dengan memindai QR-Code yang tersedia, lalu melakukan checkout hingga terjadi pembayaran, hanya saja tidak memiliki batasan wilayah untuk lokasi tertentu (Ahmed \& Al-qaraawi, 2019). Selain itu kegiatan pengabdian kepada masyarakat pun telah menggunakan QR-Code bagi pelaku UMKM, hanya saja penggunaannya sebatas pemanfaatan Facebook Marketplace sehingga masih belum dapat meningkatkan pertumbuhan ekonomi pada lokasi wilayah kabupaten Ciamis (Nursetiawan et al., 2019) .

Maka dari itu penulis tertarik untuk melakukan penelitian serta mendukung program pemerintah dalam pemberdayaan ekonomi masyarakat pada sektor market online seperti yang telah dilakukan pada distro silver squad (Suryanto, 2018). Gagasan yang penulis ajukan yaitu dengan membangun sebuah aplikasi market secara online untuk masyarakat sosial sehingga masyarakat dapat melakukan transaksi secara mandiri baik perorangan ataupun kelompok. Studi kasus yang akan dilakukan pengujian adalah lapisan elemen masyarakat pada tingkat Rukun Tetangga (RT) yang merupakan komponen akhir pembagian wilayah di Indonesia. Sehingga proses pemberdayaan ekonomi pada masyarakat bisa terfokus dan agar terlihat hasil yang signifikan jika diperlukan pengembangan, baik pada segi aplikasi maupun segi pemberdayaan itu sendiri. Tidak menutup kemungkinan jika nantinya aplikasi dapat dioperasikan pada tingkatan wilayah yang lebih tinggi dari RT, sehingga diharapkan proses pemberdayaan semakin meluas.

Berdasarkan kondisi warung tradisional yang ada, terdapat 3 warung dengan skala menengah, 2 warung dengan skala kecil, 1 warung agen besar, sehingga diharapkan potensi penjualan pada wilayah tersebut sangatlah besar. Hal ini menarik penulis untuk memberikan gagasan yang akan dimasukan kedalam fitur aplikasi agar dapat menarik daya beli masyarakat pada lingkungan tersebut. Gagasan yang penulis berikan yaitu dengan memberikan sebuah slider banner sebagai media promosi produk pada halaman awal aplikasi, sehingga dapat memberikan daya tarik terhadap masyarakat untuk membeli produk pada warung sekitar sehingga tidak kalah saing dengan minimarket yang sama jumlahnya di wilayah tersebut. Kemudian keseragaman harga juga akan disosialisasikan agar perekonomian pada warung yang ikut berpartisipasi dapat merata.

Aplikasi yang digagas akan beroperasi pada sistem Android mengingat hampir setiap masyarakat sudah memiliki smartphone dengan sistem operasi tersebut(Supatra \& Tanone, 2019). Kemudian secara garis besar rancangan sistem akan ada dua komponen yang berperan sebagai pelaku utama transaksi pada market online tersebut yaitu penjual dan pembeli. Penjual pada proses bisnis yang diajukan ditujukan kepada pedagang di lingkungan RT 03 RW 05 Kelurahan Kelapa Indah yang berperan sebagai pemasok barang kebutuhan sehari-hari yang dibutuhkan oleh masyarakat. Kemudian dibutuhkan juga peran Ketua RT sebagai Admin yang akan mengatur pendataan penjual dan pembeli, sehingga diharapkan data transaksi dapat digunakan oleh Ketua RT untuk laporan kepada pemerintah mengenai adanya program pemberdayaan ekonomi masyarakat yang sudah diaplikasikan pada lingkungan setempat.

Pada aplikasi market online menerapkan teknologi $Q R$-Code untuk mempermudah identifikasi barang yang dijual dan akan terkoneksi langsung dengan database 
sehingga proses menjadi lebih efisien dan produktivitas akan meningkat(Islam et al., 2019). Teknologi QR-Code merupakan standardisasi kode sebagai sebuah identitas pada suatu komponen atau objek tertentu. Teknologi tersebut banyak digunakan dalam berbagai bidang, salah satunya pada sistem presensi yang memiliki tingkat akurasi $98 \%$ dengan proses scan maksimal berjarak $45 \mathrm{~cm}$ (Priyambodo et al., 2020).

Dengan adanya aplikasi QR-Code, pembeli nantinya dapat menyelesaikan transaksinya secara mandiri dengan melakukan proses pindai pada $Q R$-Code yang ada pada layar aplikasi penjual. QR-Code mewakili total jumlah nominal yang harus dibayarkan oleh pembeli atas produk yang sudah dipesan sebelumnya. Pemesanan produk dapat dilakukan di mana saja dan kapan saja karena aplikasi menyediakan keranjang belanja secara virtual. Selain itu aplikasi dapat dijadikan sebagai media promosi (Segabai \& Promosi, 2018)(Kodong et al., 2012) dengan cara menampilkan katalog produk yang sudah terintegrasi dengan database produk penjual, sehingga didapatkan ragam produk yang tersedia pada toko secara real-time. Jika proses pemesanan sudah selesai maka pembeli dapat menyelesaikan transaksinya secara mandiri dengan mendatangi toko penjual atau meminta penjual untuk mengantarkan barang pesanan pembeli(Marco \& Ningrum, 2017).

\section{Metode Penelitian}

Untuk mendapatkan hasil pengujian yang maksimal maka penulis menentukan untuk menggunakan skala Rukun Tetangga (RT) terlebih dahulu agar data yang didapat bisa dianalisa untuk keperluan pengembangan kedepannya. Penulis memilih wilayah RT 03 RW 005 sebagai daerah yang dijadikan lokasi implementasi aplikasi e-market mandiri berbasis android yang akan dibangun karena penulis berdomisili pada wilayah tersebut dan kondisi geografis yang cukup potensial sebagai lokasi uji coba dan penerapan aplikasi pada tahap implementasi dan pengujian selanjutnya. Tidak menutup kemungkinan jika nantinya aplikasi dapat diterapkan pada wilayah yang lebih luas yaitu tingkat Rukun Wilayah (RW) ataupun tingkatan yang lebih tinggi yaitu Kelurahan, Kecamatan dan Provinsi.

Dari analisa yang sudah dilakukan penulis ingin membuat sebuah inovasi dengan mengajukan sistem usulan yang saling terintegrasi antara pengelola (Tingkat RT), penjual, dan pembeli agar proses jual beli dapat terlaksana secara menyeluruh dan tingkat promosi semakin besar.
Aplikasi e-market menggunakan algoritma Zbar yang diterapkan untuk membaca QR Code yang terpasang pada masing-masing komponen untuk didapatkan output utuh berupa karakter yang akan diproses lebih lanjut oleh aplikasi. Penggunaan algoritma Zbar pada aplikasi e-market berguna untuk memproses data gambar yang telah diambil oleh kamera smartphone menjadi data seutuhnya yang berupa karakter. Algoritma Zbar sendiri memanfaatkan gelombang digit kode yang tersusun pada QR Code umumnya. Algoritma Zbar tersusun dari beberapa komponen yang menunjang proses pengolahan citra gambar pada aplikasi dan dapat melakukan rotasi 3 dimensi (Sugiantoro, 2015).

Penerapan teknologi QR Code mengubah semua proses yang sebelumnya dilakukan secara manual menjadi terotomatisasi oleh sistem. Karena kode QR Code mewakili sebuah identitas barang yang terdapat pada suatu industri seperti pada industri manufaktur atau logistic dan dapat mengatasi gangguan cahaya dengan akurasi $100 \%$ (Priyambodo et al., 2020). Sehingga setiap saat dapat dilakukan proses transaksi pada barang yang sudah memiliki kode QR Code sebagai identitasnya.

Pada aplikasi e-market penggunaan kode QR Code juga mewakili sebuah identitas pada komponen tersebut untuk dilakukan proses tracking. Jika setiap komponen mempunyai identitasnya masing-masing maka komponen tersebut akan tetap dapat terpantau. Dalam dunia internasional terdapat beberapa standardisasi kode QR Code yang biasa digunakan oleh beberapa pihak baik dalam dunia industri maupun logistik.

\section{Hasil dan Pembahasan}

Pengembangan yang diusulkan pada sistem ini terdiri dari 3 aktor dalam use case diagram, yaitu admin (Pengelola Tingkat RT), Penjual dan Pembeli. Use case diagram menggambarkan relasi input dan output aktor dengan sistem seperti yang ditampilkan pada gambar 1 


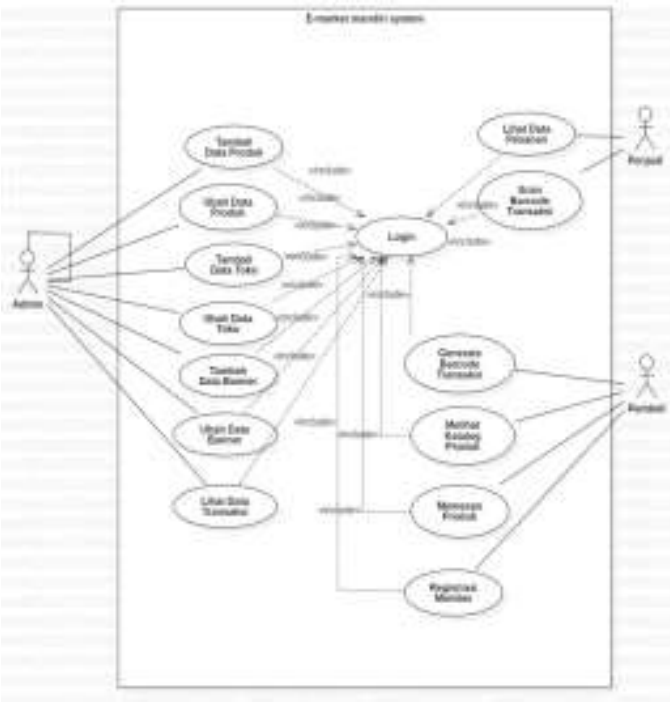

Gambar 1. Use Case Diagram Sistem E-Market

Use case diagram pada gambar 1 menjelaskan kebutuhan fungsional sistem dan menggambarkan interaksi antara admin, penjual dan pembeli. Use case diagram tersebut menjelaskan proses pembelian yang dimulai dari sisi pembeli hingga sampai pada proses simpan data ke dalam database.

Selanjutnya untuk memahami rancangan yang akan dibentuk maka dibuatlah class diagram seperti yang ditampilkan pada gambar 2. Terlihat beberapa komponen yang mendukung class diagram dengan method yang terdapat pada masing-masing aplikasi untuk melakukan action pada class tersebut.

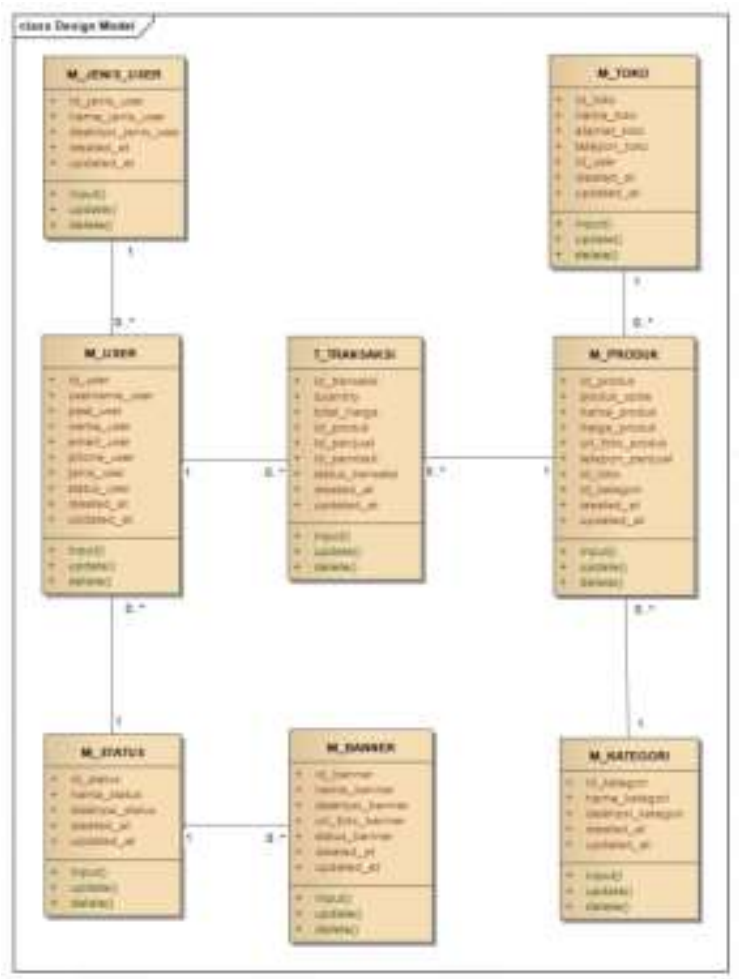

Gambar 2. Class Diagram Sistem E-Market
Di mana pada class diagram tersebut dapat kita lihat terjadinya interaksi antara pengguna (m_user) yang terdiri dari beberapa jenis pengguna ( $m$ jenis_user) melakukan transaksi (m_transaksi) terhadap produk-produk (m_produk) yang dimiliki oleh banyak toko (m_toko) dengan berbagai kategori produk (m_kategori) yang disajikan. Sehingga para pengguna tidak akan kesulitan dalam memilih produk apa yang akan dibeli berdasarkan kategori yang dipilih.

Ketika kali pertama aplikasi dijalankan oleh admin maka akan ditampilkan halaman login yang terlihat pada gambar 3 , sebelum dapat masuk pada bagian-bagian selanjutnya maka pengguna diminta untuk memasukkan username dan password masing-masing untuk menentukan hak akses dari pengguna tersebut.

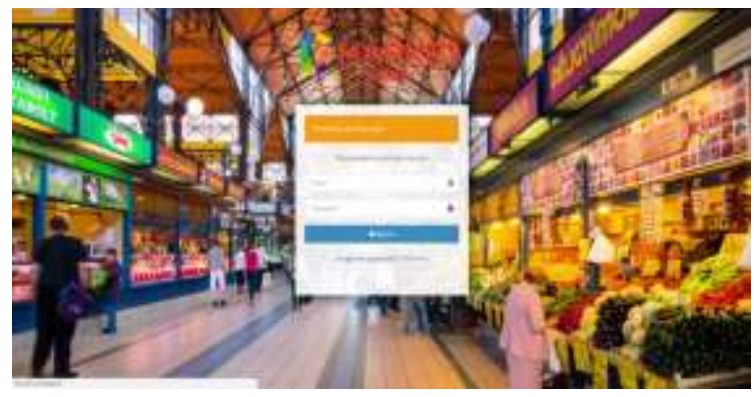

Gambar 3. Tampilan halaman login admin

Pengguna yang memiliki akses sebagai admin dapat melihat seluruh menu pada aplikasi termasuk dapat melihat produk-produk apa saja yang dimiliki oleh seluruh toko yang terdaftar pada aplikasi seperti yang ditampilkan pada gambar 4 .

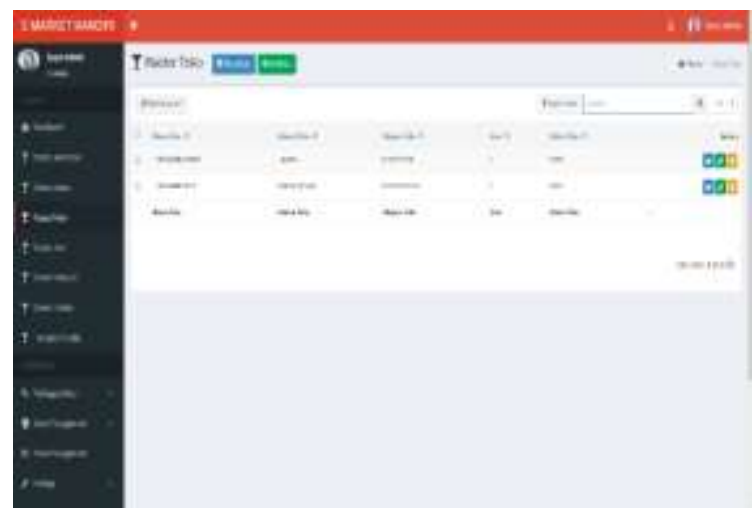

Gambar 4. Tampilan halaman produk

Aplikasi e-market selain memiliki hak akses sebagai admin dan toko, aplikasi ini juga memiliki user sebagai pembeli berbasis android dengan tampilan login seperti pada gambar 5 . 


\section{Gambar 5. Tampilan halaman login android}

Setelah berhasil login akan ditampilkan produk-produk apa saja yang dijual pada aplikasi e-market tersebut dengan tampilan seperti pada gambar 6 .

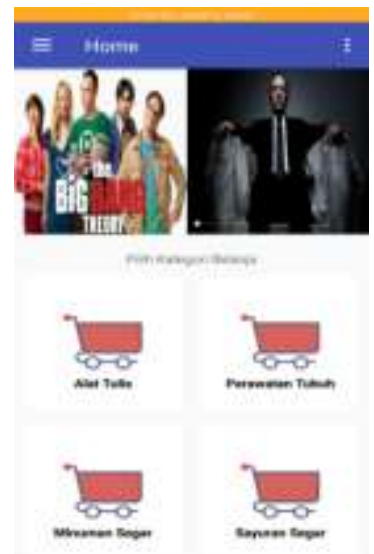

Gambar 6. Tampilan halaman home aplikasi

Selanjutnya pada gambar 7 ditampilkan halaman untuk melakukan scan barcode yang digunakan sebagai verifikasi penjualan dan pembelian produk.

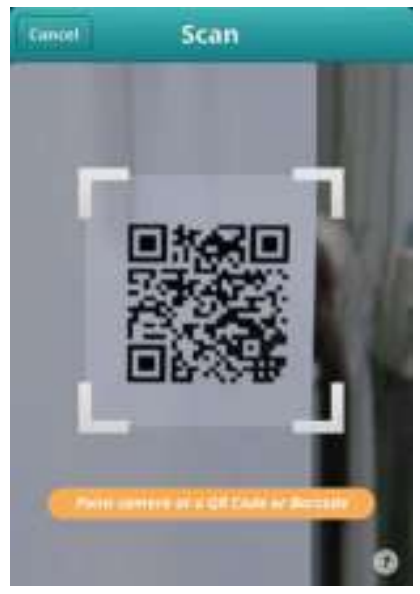

Gambar 7. Tampilan halaman scan QR-Code

Algoritma Zbar pada aplikasi E-MARKET berguna untuk memproses data gambar yang telah diambil oleh kamera smartphone menjadi data seutuhnya yang berupa karakter. Algoritma
Zbar sendiri memanfaatkan gelombang digit kode yang tersusun pada kode $Q R$ Code umumnya. Algoritma Zbar tersusun dari beberapa komponen yang menunjang proses pengolahan citra gambar pada aplikasi.

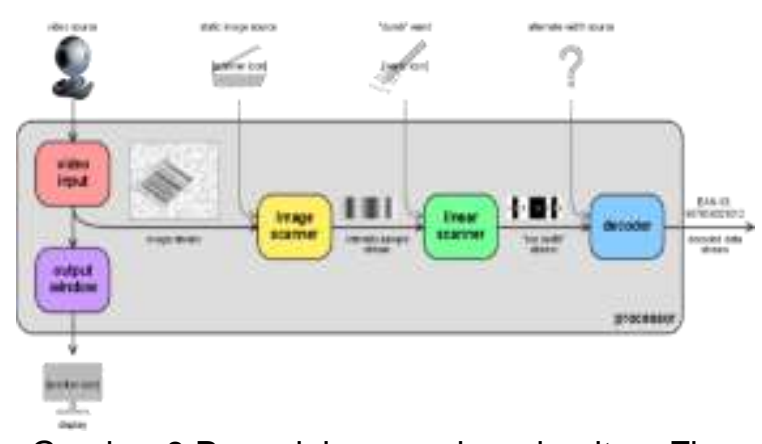

Gambar 8 Pengolahan gambar algoritma Zbar

Berdasarkan skema pada gambar 8 maka proses pengolahan gambar menjadi data seutuhnya pada algoritma Zbar adalah sebagai berikut :

1) Video input melakukan pengambilan citra pada kode $Q R$ Code yang tersedia;

2) Image scanner mendapatkan citra kode $Q R$ Code dan kemudian melakukan scan pada intensitas gelombang citra kode $Q R$ Code menggunakan teknik scan 2 dimensi;

3) Linear scanner mendapatkan sampel gambar abstrak berupa sampel intensitas pada citra gambar dan kemudian melakukan scan pada sampel intensitas tersebut untuk mendapatkan hasil lebar digit kode $Q R$ Code dengan meggunakan teknik scan 1 dimensi;

4) Decoder akan melakukan identifikasi pada lebar digit kode $Q R$ Code berdasakan pattern yang sudah didaftarkan pada library untuk menghasilkan data seutuhnya berupa output standar karakter $Q R$ Code (EAN, UPC, Code-128).

Algoritma yang sudah dijelaskan merupakan algoritma yang digunakan dalam proses pembacaan kode $Q R$ Code pada aplikasi E-MARKET. Pada aplikasi E-MARKET digunakan dua standar kode $Q R$ Code yang diproses oleh algoritma Zbar yaitu EAN dan UPC. Proses decoding yang dilakukan algoritma Zbar berdasarkan lebar digit kode yang didapatkan pada saat proses linear scanner.

Sampel lebar digit kode tersebut mewakili ukuran lebar dari karakter yang diwakilinya. Berikut adalah sampel gambar yang digunakan oleh algoritma Zbar untuk dapat mengidentifikasi lebar dari digit kode tersebut.

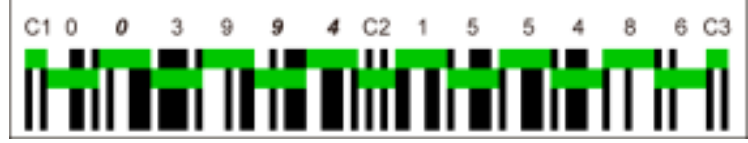

Gambar 9 Sampel ukuran digit kode QR Code 
Pada gambar 9 dapat dilihat digit kode yang mewakili masing-masing karakter angka yang diwakilinya. Karakter C1 dan C3 menandakan dimana scanner akan memulai proses awal pembacaan dan akhir pembacaan. Kemudian pada masing-masing digit yang terdapat pada gambar tersebut akan dapat teridentifikasi oleh algoritma Zbar berdasarkan perhitungan lebar yang sudah ditentukan pada library yang terapat pada algoritma Zbar untuk mendapatkan hasil akhir yaitu data yang utuh.

Selanjutnya berdasarkan hasil pengujian yang dilakukan pada sistem untuk beberapa data uji, maka dihasilkan pengujian tersebut seperti pada table 2 .

Table 2. Table hasil pengujian

\begin{tabular}{|c|c|c|c|}
\hline Deskripsi & $\begin{array}{l}\text { Prosedur } \\
\text { Pengujian }\end{array}$ & $\begin{array}{c}\text { Hasil yang } \\
\text { didapat }\end{array}$ & Hasil \\
\hline $\begin{array}{l}\text { Validasi } \\
\text { Login }\end{array}$ & $\begin{array}{l}\text { memasukkan } \\
\text { username dan } \\
\text { password }\end{array}$ & $\begin{array}{l}\text { Berhasil login } \\
\text { dan masuk ke } \\
\text { halaman utama }\end{array}$ & sukses \\
\hline $\begin{array}{l}\text { Tambah } \\
\text { Data } \\
\text { Produk }\end{array}$ & $\begin{array}{c}\text { memasukan } \\
\text { data produk } \\
\text { baru ke sistem }\end{array}$ & $\begin{array}{l}\text { Data tampil } \\
\text { pada layar }\end{array}$ & sukses \\
\hline $\begin{array}{l}\text { Ubah Data } \\
\text { Produk }\end{array}$ & $\begin{array}{c}\text { melakukan } \\
\text { perubahan data } \\
\text { produk }\end{array}$ & $\begin{array}{l}\text { Data tampil } \\
\text { pada layar }\end{array}$ & sukses \\
\hline $\begin{array}{c}\text { Tambah } \\
\text { Data Toko }\end{array}$ & $\begin{array}{l}\text { memasukan } \\
\text { data toko baru } \\
\text { ke sistem }\end{array}$ & $\begin{array}{l}\text { Data tampil } \\
\text { pada layar }\end{array}$ & sukses \\
\hline $\begin{array}{l}\text { Ubah Data } \\
\text { Toko }\end{array}$ & $\begin{array}{l}\text { melakukan } \\
\text { perubahan data } \\
\text { toko }\end{array}$ & $\begin{array}{l}\text { Data tampil } \\
\text { pada layar }\end{array}$ & sukses \\
\hline $\begin{array}{l}\text { Tambah } \\
\text { Data } \\
\text { Banner }\end{array}$ & $\begin{array}{c}\text { memasukan } \\
\text { data banner } \\
\text { baru ke sistem }\end{array}$ & $\begin{array}{l}\text { Data tampil } \\
\text { pada layar }\end{array}$ & sukses \\
\hline $\begin{array}{c}\text { Ubah Data } \\
\text { Banner }\end{array}$ & $\begin{array}{c}\text { melakukan } \\
\text { perubahan data } \\
\text { banner }\end{array}$ & $\begin{array}{l}\text { Data tampil } \\
\text { pada layar }\end{array}$ & sukses \\
\hline $\begin{array}{l}\text { Lihat Data } \\
\text { Transaksi }\end{array}$ & $\begin{array}{c}\text { membuka data } \\
\text { transaksi }\end{array}$ & $\begin{array}{c}\text { Berhasil } \\
\text { menampilkan } \\
\text { data transaksi }\end{array}$ & sukses \\
\hline $\begin{array}{l}\text { Lihat Data } \\
\text { Pesanan }\end{array}$ & $\begin{array}{c}\text { Penjual } \\
\text { membuka data } \\
\text { pesanan }\end{array}$ & $\begin{array}{c}\text { Berhasil } \\
\text { menampilkan } \\
\text { data pesanan }\end{array}$ & sukses \\
\hline $\begin{array}{c}\text { Scan } \\
\text { Barcode }\end{array}$ & $\begin{array}{l}\text { Penjual } \\
\text { melakukan } \\
\text { proses klik } \\
\text { button scan }\end{array}$ & $\begin{array}{c}\text { Berhasil } \\
\text { menampilkan } \\
\text { citra gambar }\end{array}$ & sukses \\
\hline $\begin{array}{l}\text { Generate } \\
\text { Barcode }\end{array}$ & $\begin{array}{c}\text { Pembeli } \\
\text { melakukan } \\
\text { proses klik } \\
\text { button generate }\end{array}$ & $\begin{array}{c}\text { Berhasil } \\
\text { menampilkan } \\
\text { citra barcode }\end{array}$ & sukses \\
\hline $\begin{array}{l}\text { Lihat } \\
\text { Katalog } \\
\text { Produk }\end{array}$ & $\begin{array}{l}\text { Pembeli melihat } \\
\text { katalog produk }\end{array}$ & $\begin{array}{c}\text { Berhasil } \\
\text { menampilkan } \\
\text { katalog produk }\end{array}$ & sukses \\
\hline $\begin{array}{l}\text { Memesan } \\
\text { Produk }\end{array}$ & $\begin{array}{l}\text { Pembeli } \\
\text { melakukan } \\
\text { pemesanan } \\
\text { produk }\end{array}$ & $\begin{array}{l}\text { Berhasil } \\
\text { memesan } \\
\text { produk }\end{array}$ & sukses \\
\hline $\begin{array}{l}\text { Registrasi } \\
\text { Member }\end{array}$ & $\begin{array}{l}\text { Pembeli } \\
\text { melakukan } \\
\text { register akun }\end{array}$ & $\begin{array}{l}\text { Berhasil } \\
\text { mendaftar }\end{array}$ & sukses \\
\hline
\end{tabular}

\section{Verifikasi Pengujian Aplikasi}

Hasil kuisioner yang diberikan kepada beberapa pengguna aplikasi dengan kriteria penilaian seperti pada table 3 .

Table 3. Penjelasan Penilaian

\begin{tabular}{ll}
\hline Kode & \multicolumn{1}{c}{ Keterangan } \\
\hline A & Peningkatan Jumlah Penjualan \\
B & Kemudahan Transaksi Penjualan \\
C & Promosi Produk \\
D & Jangkauan Penjualan \\
E & Pemanfaatan Perangkat Mobile \\
\hline
\end{tabular}

Sehingga dihasilkan dari penyebaran kuesioner tersebut sebanyak $90 \%$ mengalami peningkatan penjualan yang signifikan dan sebanyak $90 \%$ berhasil mempromosikan produk yang dijualnya seperti yang nampak pada gambar 10. Sebanyak 94,4\% responden memberikan penilaian yang sangat baik untuk hasil penjualan menggunakan aplikasi e-market mandiri.

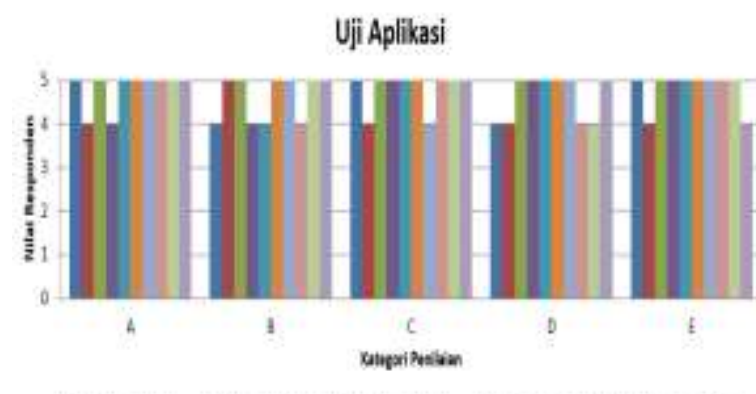

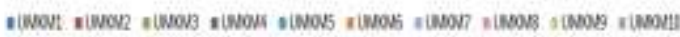

Gambar 10. Penilaian e-Market Mandiri

\section{Kesimpulan}

Dari penelitian yang sudah dilakukan maka dapat diambil kesimpulan bahwa aplikasi e-market mandiri dapat memudahkan proses transaksi jual beli sebanyak $90 \%$ dan promosi produk penjualan sebanyak $90 \%$ sehingga dapat meningkatkan daya beli masyarakat. Selain itu aplikasi ini berjalan pada perangkat android dengan memanfaatkan kamera sebagai media input untuk membaca barcode yang digunakan sebagai verifikasi data pembelian. Pertukaran data yang dilakukan oleh clientserver menggunakan sebuah layanan webservice yang berjalan pada environment Apache. Aplikasi ini berbasis mobile device (android) yang ditujukan untuk memudahkan pengembangan aplikasi pada masa mendatang, dan jika diperlukan penambahan fitur serta perubahan aplikasi yang signifikan seiring dengan perkembangan teknologi yang sangat pesat.

Selanjutnya dari hasil penelitian ini untuk kedepannya adalah pemanfaatan dan pengembangan aplikasi diharapkan dapat dilakukan pada tingkat yang lebih tinggi dari 
tingkat RT. Selain itu pemanfaatan e-money pada aplikasi juga dapat diterapkan dikemudian hari untuk menambah kesan praktis pada penggunaan aplikasi.

\section{Referensi}

Ahmed, B., \& Al-qaraawi, S. (2019). Design and Implementation of e-Shopping System Using QR Code and Smart Mobile Phone. Iraqi Journal of Computer, Communication, Control and System Engineering, 19(3), 56-64.

https://doi.org/10.33103/uot.ijccce.19.3.6

Darussalam, J. S. (2018). Strategi Warung Tradisional Dalam Menghadapi Ekspansi Minimarket Modern Di Banjarmasin. 2(2), 25-52.

Gunawan, W. (2019). ERP System As A Inventory Control And Waste Elimination (Pt Vif Case Study). International Journal of Computer Trends and Technology (IJCTT), 67(7), 8-13.

Islam, A., Sharmin, M., \& Sakib, N. (2019). A Study on Multiple Barcode Detection from an Image in Business System. International Journal of Computer Applications, 181(37), 30-37. https://doi.org/10.5120/ijca2019918340

Kodong, F. R., Kaswidjanti, W., \& Setiyawan, A. (2012). MODEL APLIKASI E-MARKET SEBAGAI SARANA PROMOSI DAN TUKAR MENUKAR INFORMASI. Telematika, 8(2), 75-84.

Made, I. D., Santosa, C., Luh, N., Norma, P., Abdi, D., Suprapto, P. A., Luh, N., Kartika, A., \& Sarja, Y. (2020). Pemanfaatan Media Pemasaran Online dan Diversifikasi Produk Untuk Keberlangsungan Usaha Telur Asin. 1(4), 156-164.

Marco, R., \& Ningrum, B. T. P. (2017). Analisis Sistem Informasi E-Marketplace Pada Usaha Kecil Menengah (Ukm) Kerajinan Bambu Dusun Brajan. Jurnal IImiah DASI, 18(2), 48-53.
Nursetiawan, I., Endah, K., \& Sujai, I. (2019). Digitalisasi Produk Unggulan Desa Sukamaju Kecamatan Cihaurbeuti Kabupaten Ciamis Berbasis Qr Code Dan Facebook Marketplace. Abdimas Galuh, 1(1), 67. https://doi.org/10.25157/ag.v1i1.2885

Priyambodo, A., Usman, K., Novamizanti, L., Telekomunikasi, T., Telkom, U., \& Korespondensi, P. (2020). Implementasi Qr Code Berbasis Android Pada Sistem Presensi. $7(5)$. https://doi.org/10.25126/jtiik.202072337

Putra, T. A., \& Dwiasnati, S. (2020). Rancang Bangun Aplikasi Investasi Ukm Berbasis Web Dengan Fitur Penentuan Resiko Bisnis. Csrid Journal, 12(2), 117-128.

Ristekbrin. (2017). Smartphone Rakyat Indonesia.

Https://Www.Ristekbrin.Go.Id/Siaran-

Pers/Smartphone-Rakyat-Indonesia-2/.

Segabai, P. Q., \& Promosi, M. (2018). Jurnal MNEMONIC. 1(2), 56-61.

Statistik e-Commerce $2019 . \quad$ (2019). Https://Www.Bps.Go.Id/Publication/2019/1 2/18/Fd1e96b05342e479a83917c6/Statisti k-e-Commerce-2019. Html.

Sugiantoro, B. (2015). Pengembangan Qr Code Scanner Berbasis Android Untuk Sistem Informasi Museum Sonobudoyo Yogyakarta. Telematika, 12(2), 134-145. https://doi.org/10.31315/telematika.v12i2.1 410

Supatra, D. R. I., \& Tanone, R. (2019). PERANCANGAN APLIKASI BUS FTI UKSW MENGGUNAKAN BARCODE BERBASIS ANDROID. Jurnal Sistem Informasi Dan Tenologi, 2(2), 151-164.

Suryanto, T. (2018). Penerapan E-Marketplace pada Distro Silver Squad. 1, 8-9.

Yuniar, M. D. (2020). Aplikasi instagram sebagai sarana promosi bisnis online : sebuah studi pada akun warung mamak. 02(03), 1-9. 